УДК 378.4:61(477.85)(09)БДМУ

\section{Тарас БОЙЧУк,} АНтоній МОЙСЕЙ

ВДНЗ України «Буковинський державний медичний університет», Чернівці (Україна)

\section{Taras BOYCHUK,} Antoniy MOYSEY

Higher State Educational Establishment

of Ukraine «Bukovinian State Medical University»

Chernivtsi (Ukraine)

rector@bsmu.edu.ua

antoniimoisei@bsmu.edu.ua

ORCID ID: 0000-0001-5295-2271

\author{
ОРГАНІЗАЦЯ НАУКОВОЇ ДІЯЛЬНОСТІ \\ ЧЕРНІВЕЦЬКОГО ДЕРЖАВНОГО \\ МЕДИЧНОГО ІНСТИТУТУ В 1944-1954 РP.
}

\author{
STRUCTURE OF SCIENCE RESEARCH IN \\ CHERNIVTSI STATE MEDICAL INSTITUTE
}

(1944-1954 YEARS).
Ключевые слова: Черновицкий государственный медицинский институт, научно-исследовательская работа, научный потенциал, проблемная комиссия, профессорсько-преподавательский состав, аспирантура, клиническая ординатура, студенческое научное общество, научная библиотека.

Бойчук Тарас, Мойсей Антоний. Организация научной деятельности Черновицкого государственного медицинского института в 1944-1954 гг.

В статье отражена история организации научноисследовательской работы Черновицкого госсудраственного медицинского университета в 1944-1954 гг., в частности рассмотрены вопросы относительно формирования первых проблемних комиссий, порядка утверждения комплексних научных тем кафедр, планирования и защиты диссертационных работ, издания первых монографий и институтских сборников научных работ, основания и деятельности студенческого научного общества, закрепления за кафедрами аспирантов и клинических ординаторов, расширения материальной базы и фонда библиотеки ЧГМИ.

Вступ. Буковинський державний медичний університет пройшов довгий і складний шлях від інституту й академії до університету. Цей часовий відрізок позначений вагомими досягненнями його співробітників у різних галузях медицини.

Здобутки професорсько-викладацького складу навчального закладу стали яскравими сторінками історії розвитку медичної науки в Україні. Насамперед це стосується періоду становлення наукових шкіл та визначення напрямку їх експериментальних досліджень, які й донині посідають чільне місце в магістральному тренді розвитку вітчизняної медичної науки. За більш ніж 70-річний період декілька поколінь викладачів -науковців, клініцистів, талановитих студентів примножили славу своєї Alma mater, забезпечивши університетові лідерські позиції серед вищих медичних закладів України.

Одним 3 найцінніших надбань університету, його золотим фондом $є$ наукові школи, більшість з яких почала формуватись ще в $1940-1950-x$ рр., тобто у перші роки його існування. Наразі плідно функціонують наукові школи з терапії, психіатрії, неврології, офтальмології, гістології, патологічної анатомії, що пов'язані з іменами таких вчених, як: С.М. Савенко, В.А. Трігер, Б.Л. Радзіховський, Н.М. Шінкерман, Н.Б. Щупак, Г.Ю. Маліс, І.А. Шевчук та ін.

Результати історіографічного огляду літератури засвідчують необхідність доповнити попередні дослідження цього часового відрізка в зазначеному тема- тичному аспекті даними, знайденими в нових архівних матеріалах та інших джерелах. Мета роботи продовжити цикл авторських статей з історії розвитку БДМУ (Чернівецького державного медичного інституту, Буковинської державної медичної академії) ${ }^{1}$, проаналізувати діяльність навчального закладу щодо організації наукової роботи в 1944-1954 pp.

Основна частина. Постанову про відкриття у м. Чернівцях медичного інституту (№ 1360 РНК УРСР «Про відновлення роботи 2-го Київського медичного інституту») підписано 20 жовтня 1944 р. М. Хрущовим. Новостворений навчальний заклад наприкінці листопада 1944 р. (після завершення набору студентів на I курс, укомплектування його кадрами) було перейменовано у «Чернівецький державний медичний інститут», а для засвідчення офіційних документів видано нову печатку. На той час у виші навчалося 357 студентів, а перший професорського- викладацький налічував 144 особи, з-поміж яких - 5 професорів, 5 доцентів, 18 кандидатів наук, що стали інтелектуальною основою перших теоретичних і клінічних кафедр. В. о. директора Чернівецького державного медичного інституту призначено С.I. Кефелі, який у жовтні 1941 p. та листопаді 1943 р. виконував обов'язки директора I Київського медичного інституту.

Колектив інституту активно включився в педагогічну, науково-дослідну та лікувальну роботу, що дало позитивні результати: через 10 років у ВНЗ було 
вже 17 професорів і докторів наук, 27 доцентів та 37 кандидатів наук, а кількість студентів перевищила 1200 осіб. Інститут запрацював як освітній, науковий, лікувальний і культурний осередок області.

Варто зазначити, що навчальний заклад створювався в тяжкі повоєнні часи, У вкрай несприятливих епідемічних, кліматичних і побутових умовах. Крім того, на організацію професійної діяльності його викладачів негативно впливала партійна ідеологія, що насаджувалась тотально: не тільки під час викладання суспільно-гуманітарних дисциплін, а й у межах фахових і медико-біологічних наук.

У перші роки діяльності Інституту були серйозні проблеми щодо опалювання навчальних приміщень, їх водозабезпечення, електропостачання, 3 а також доставки хліба. Згодом директор О.Д. Юхимець відновлював у пам'яті картину тих днів: «Лекиійні зали, лабораторії, гуртожитки були настільки бідно обладнані, щзо студентам не було на чому сидіти. Табуретки, звичайні дошки, укладені на підставках з иегли чи табуреток були звичайним явищем. На кафедрі гістології в перші роки роботи не вистачало звичайних табуреток, було всього 2 мікроскопи, один набір гістологічних препаратів, один мікроскоп приходився на 50-60 студентів, $і$ щуоб подивитись препарат, необхідно було стояти в черзі. Аналогічна обстановка була і на кафедрах нормальної та патологічноі анатомії, оперативної хірургії $і$ топографічної анатомії та на інших кафедрах ...». Рядки настінної газети 1964 р., написані випускниками 1949 року передають умови роботи цього часу на кафедрі оперативної хірургії й оперативної анатомії: «Нетоплена, напівтемна кімната, щчо служила колись каплицею, слугувала одночасно аудиторією та секційним залом. Зі стін докірливим поглядом спостерігали лики святих, стеля зображувала зоряне небо, і на иьому священному тлі вимальовувалась прозайчна фігура проф. Гуляницького в шубі та довгій овечій шапиі» ${ }^{2}$.

У перші роки своєї діяльності інститут розташо- вувався в приміщеннях чотирьох будівель: на Театральній площі, 5 (нині центральний корпус БДМУ на Театральній площі), колишньої стоматологічної, а пізніше очної лікарні по вул. Балмаша, 3 (сьогодні це морфологічний корпус по вул. Ризькій, 3), колишнього гуртожитку учнів школи «Ion Nistor» по вул. Т. Масарика, 2 (сьогодні це теоретичний корпус по вул. Богомольця, 2) та по вул. О. Кобилянської, 42. Кількість кафедр варіювало від 32 до 34. Клінічними базами ВНЗ були: обласна і міська лікарні, обласна дитяча лікарня, психіатрична лікарня, пологовий будинок, госпіталь інвалідів Великої Вітчизняної війни, туберкульозна лікарня, залізнична лікарня, перша і друга міські поліклініки та диспансери.

Зазначені роки - це період остаточного укомплектування першого професорсько-викладацького складу ЧДМІ, до якого входили: Ф.А. Баштан, М.Г. Безюк, М.К. Венцківський, Г.А. Водатурський, 3.Н. Гржебін, Ф.М. Гуляницький, В.А. Ельберг, С.П. Закривидорога, Л.Н. Заманський, М.М. Зотін, Г.П. Каліна, А.В. Кірілічева, Б.І. Кранцфельд, Е.Р. Кратінова, Д.Г.Крічін, С.К. Лобинцев, О.Ю. Мангейм, М.I. Михалойц, М.П. Новіков, Б.К. Осіпов, М.Д. Пекарський, Б.Л. Радзіховський, М.Ю. Рапопорт, Б.Б. Роднянський, С.М. Савенко, Я.П. Скляров, Н.П. Татаренко, Л.Б. Теодор, В.А. Трігер, О.О. Троїцький, І.Г. Федоров, О.М. Федорович, К.Д. Філатова, Є.Р. Цитрицький, Д.С. Четвертак, І.А.Шевчук, Н.М. Шінкерман, Н.Б. Щупак та ін.

Станом на 1 січня 1955 р. у ЧДМІ було 17 докторів наук, професорів: Ф.А. Баштан, С.П. Закривидорога, З.Н. Гржебін, Г.П. Каліна, Я.Д. Кіршенблат, Г.Ю. Маліс, О.Ю. Мангейм, В.С. Нікітський, В.В. Попов, Б.Л. Радзіховський, С.М. Савенко, Л.Б. Теодор, В.А. Трігер,О.М. Федорович, Є.Р. Цитрицький, Д.С. Четвертак, Н.Б. Щупак ${ }^{3}$ (див. табл. № $1)$.

Таблиця № 1

Професорсько-викладацький склад ЧДМІ в 1944-1954 pp.

\begin{tabular}{|c|c|c|c|c|c|}
\hline $\begin{array}{c}\text { Навчальні } \\
\text { роки }\end{array}$ & $\begin{array}{c}\text { Професори, } \\
\text { доктори наук }\end{array}$ & Доценти & $\begin{array}{c}\text { Асистенти, } \\
\text { викладачі } \\
\text { (кандидати } \\
\text { наук) }\end{array}$ & $\begin{array}{c}\text { Асистенти, ви- } \\
\text { кладачі (без } \\
\text { наук. ступеня) }\end{array}$ & Всього \\
\hline $1944-1945$ & 5 & 5 & 18 & 116 & 144 \\
\hline $1945-1946$ & 7 & 6 & 15 & 148 & 176 \\
\hline $1946-1947$ & 11 & 7 & 24 & 124 & 166 \\
\hline $1947-1948$ & 13 & 11 & 27 & 83 & 134 \\
\hline $1948-1949$ & 14 & 9 & 30 & 82 & 135 \\
\hline $1949-1950$ & 14 & 10 & 33 & 79 & 136 \\
\hline $1950-1951$ & 14 & 12 & 35 & 62 & 136 \\
\hline $1951-1952$ & 14 & 15 & 40 & 72 & 131 \\
\hline $1952-1953$ & 14 & 20 & 41 & 89 & 147 \\
\hline $1953-1954$ & 15 & 21 & 40 & 70 & 165 \\
\hline $1954-1955$ & 17 & 27 & 37 & & 151 \\
\hline
\end{tabular}


Варто зазначити, що перший професорськовикладацький склад інституту формували видатні науковці, викладачі зі стажем, клініцисти з провідних вищих навчальних закладів, науково-дослідних інститутів, медичних установ Росіі, Білоруської РСР, Молдавськоӥ РСР, Азербайджанської РСР, Казахської РСР, Киргизької РСР, Дагестанської АРСР, Таджсицькоӥ РСР, Узбецькой РСР і Украйнськоӥ РСР. Частина цих науково-педагогічних працівників отримала професійний досвід у Франції, Німеччині, Польщі. Деяких з них за сумлінну багатолітню працю було нагороджено орденом Трудового Червоного Прапора, «Знаком пошани», знаком «Відмінник охорони здоров'я», вони стали фундаторами наукових шкіл Чернівецького державного медичного інституту.

Незважаючи на позитивні зрушення, у перші роки організації Інституту робота з укомплектування кафедр професорсько-викладацькими кадрами проводилася вкрай повільно. Найбільшою проблемою була недостатня кількість професорів - постійних завідувачів кафедр.

Кафедри починали свою роботу з нуля: зі створення лабораторій, музеїв, загальноінститутської та кафедральних бібліотек, впорядкування архівів. Їм бракувало приміщень. Також вони були недостатньо забезпечені навчальною літературою та методичними матеріалами, не мали й належного обладнання.

У 1946-1954 pр. матеріально-технічні бази кафедр дещо покращилися й вони почали активну наукову роботу. Так, на кафедрі госпітальної терапії організовано лабораторію 3 дослідження крові; на кафедрі нормальної фізіології виготовлено вівісекційні столи і станки для проведення дослідів на собаках; на кафедрі психіатрії організовано лабораторію вищої нервової діяльності, де широко застосовувалася терапія сном, гіпнотерапія ${ }^{4}$; на кафедрі факультетської терапії у 1945-1954 pр. було обладнано 13 лабораторій та кабінетів для проведення науково-дослідної роботи: клінічну лабораторію (1945), рентгенотерапевтичний кабінет (1945), рентгенодіагностичний кабінет (1946), біохімічну лабораторію (1948), фізіотерапевтичний кабінет (1949), кабінет ректороманоскопії (1950), кабінет кисневої терапії (1952), електрокардіографічний кабінет (1952), кабінет основного обміну (1952), кабінет функціональної діагностики (1954), гастроскопічний кабінет (1954), лабораторію радіоактивних ізотопів (1954), кабінет для роботи 3 лічильником для радіоактивних ізотопів $(1954)^{5}$; на кафедрі нормальної анатомії організовано музей, який у 1946 -1947 рр. розміщувався у двох кімнатах і мав п'ять відділів (остеології, синдесмології, міології, ангіоневрології, спланхологіï) ${ }^{6}$.

На підставі проведеного аналізу звітів кафедр за цей період, можна зробити висновок про те, що підрозділи інституту вже мали той необхідний мінімум, який дзволяв їм самостійно та, основне, якісно виконувати наукову роботу.

Отже, 1945 був роком організації та становлення наукової роботи інституту. Низка кафедр зробила перші кроки в самостійній науковій діяльності. Решта ж кафедр звітувала про ті науково-дослідні робо- ти, що були розпочаті їхніми співробітниками в інших інститутах та продовжені у ЧДМІ. Наприклад, під час I наукової сесії ЧДМІ, яка відбулася 20-21 липня 1945 р., було заслухано 17 доповідей, 3 яких 5 доповідей представляли результати клінічних спостережень проведених в інституті, як-от: проф. Федорович О.М. (кафедра педіатрії) - «Копрологічне обстеження дітей для вивчення топографічних особливостей інфекції за даними дитячої лікарні м. Чернівці»; асист. Сєргєєва (кафедра педіатрії) - «Глистяні інвазії у дітей за даними дитячих лікарень м. Чернівці»; асист. Федотьєва К.С. (кафедра педіатрії) «Лямбліоз у дітей за даними клініки дитячих хвороб ЧДМІ»; доц. Безюк М.Г. (кафедра венеричних хвороб) - «Венеричні захворювання в Чернівецькій області за даними клініки ЧДМІ»; асист. Савіних I.I. (кафедра факультетської хірургії) - «Гангрена після висипного тифу за даними обласної клінічної лікарні»».

На II науковій сесії ЧДМІ, проведеній 9 грудня 1945 р., кількість доповідей (у відсотковому співвідношенні), що базувались на місцевому матеріалі, зросла (5 з 10). 3-поміж них потрібно відзначити оригінальні роботи, в яких запропоновано нові методи хірургічного втручання: проф. Михалойц M.I. (кафедра отолярингології) «Новий хірургічний метод лікування синехій порожнини носа (м'яких)»; професор Цитрицький Є.P. (кафедра факультетської хірургіï) - «Транслакунарний доступ до судин малого тазу»; піднімалися маловивчені питання в медицині: доц. Філатова К.Д. (кафедра нормальної анатомії) - «Макро-мікроскопія хрящового остова бронхів»; проф. Венцківський М.К. (кафедра акушерства та гінекології) - «До питання про переважаючих шляхах розповсюдження рака шейки матки» та ін.

У 1945-1946 н. р. конференції організовували й окремі кафедри. Крім того багато співробітників інституту доповідали на засіданнях пленуму та секцій Чернівецького медичного товариства, а також на всеукраїнських з'їздах (наприклад, педіатрів - у Києві, біохіміків і фізіологів - у Львові та ін.).

Проте низка чинників ускладнювала виконання наукового плану: брак обладнання, віваріїв, а як наслідок складність експериментування над тваринами. Та особливо позначався брак наукової літератури. Це підтверджується джерельними даними про планування науково-дослідної роботи на кафедрі біології у 1945 р., як-от: зібрати колекцію комах та хребетних тварин, приготувати нові препарати (Vermes, Mollusca, Crustacea та ін.), мікропрепарати та експонати 3 паразитології, виготовити не менше 10 скелетів, чучел птахів та ссавців, таблиці з курсу «Загальна біологія» (за допомогою студентів - активних членів студент. наукового гуртка кафедри $)^{7}$.

Варто зазначити, що в 1945 р. у ЧДМІ точилася дискусія щодо визначення загальної (провідної) тематики НДР закладу, в руслі якої обирали б теми кафедр. В основному вона велася на засіданнях ради професорів, з-поміж яких були прихильники питання вивчення зобної ендемії в Чернівецькій області. Їхні опоненти категорично виступали проти вибору однієї теми, наголошуючи на тому, що ЧДМІ не є науково- 
дослідним інститутом, де одна проблема $\epsilon$ обов'язковою для всіх кафедр. Таким чином, погляди науковців щодо цього питання розділилися. У результаті деякі кафедри обрали теми пов'язані 3 дослідженням ендемічного зоба. Зокрема, було виконано науково-дослідні роботи в руслі цієї тематики: «Стан венозної системи при зобі», «Венозний тиск у хворих на зоб», «Швидкість (час) кровообігу у хворих на зоб» (кафедра діагностики 3 окремою патологією); «Ендемічний зоб у Чернівецькій області», «Вплив гіпофіза хворого на ендемічний зоб на щитовидну залозу. Експериментальне дослідження», «Патоморфологія ендемічного зоба в Чернівецькій області», «Вміст крові в щитовидній залозі хворого на ендемічний зоб за даними Чернівецької області», «Гематологічні дані при ендемічному зобі залежно від його форм у Чернівецькій області» (кафедра факультетської хірургії) ${ }^{8}$. Деякі кафедри присвятили цій проблематиці не одну тему, наприклад: «Психопатологічні особливості осіб, що страждають на ендемічний зоб» (одна 3 3-х тем кафедри психіатpii), «Патоморфологія ендемічного зоба на Буковині» (одна 3 5-ти тем кафедри патологічної анатомії), "Розвиток та іннервація щитовидної залози" (пізніше тему змінено на «Морфологія ендемічного зоба в Чернівецькій області») (одна з 4-х тем кафедри гістологіi), «Захворюваність на паразитарні тифи серед хворих на зоб» та «Зростання імунітету при вакцинації хворих на зоб» (дві з 4-х тем кафедри мікробіології), «Ендемічний зоб Північної Буковини та його хірургічне лікування» (одна із 7-и тем кафедри загальної хірургії) та ін.

Були кафедри, які розробляли теми присвячені водночас трьом і більше загальноінститутським проблемам. Наприклад, кафедра нервових хвороб займалась насамперед дослідженням «Сифілісу нервової системи» (теми: «Ураження нервової системи при первинному сифілісі», «Ранні сифілітичні менінгіти» - обидві розроблялися проф. С.М. Савенко); проте виконувала й тему в руслі тематики ендемічного зоба (тема: «Патогістологічні зміни нервової системи»); а також в аспекті досліджень нейроінфекцій (теми: «До проблеми енцефаломієліту», «Первинні енцефаломієліти») ${ }^{9}$.

Більшість кафедр виконувала НДР не пов'язані з дослідженням проблем зоба. На 1945 р. було затверджено такі теми: «Фауна Північної Буковини», «Рептилії Чернівецької області», «Біологічні особливості розмноження місцевих видів хвостатих амфібій» (кафедра загальної біології), «Родопоміч у Північній Буковині» (кафедра організації охорони здоров’я), «Клініко-психопатологічні особливості симптоматичних психозів», «Пізні наслідки закритих травм черепа» (кафедра психіатрії), «Епідеміологія Чернівецької області» (Д.С. Ловля, А.Г. Сомова), «Підвищення імунітету при вакцинації у хворих на сифіліс» (кафедра мікробіології), «До питання про шляхи поширення рака шийки матки», «Гормональне перевантаження у вагітних самиць кролів», «Взаємовідносини між гормональною секрецією i мінеральним обміном у вагітних, породіллі і родильниць», «До питання вживання граміцидину в акушер- сько-гінекологічній практиці», «Віддалені наслідки оперативного лікування рака шийки матки», «Пеніцилін при септичних післяродових і післяабортових захворюваннях» (кафедра акушерства і гінекології), «Патоморфологія раневих артритів», «Патологічна анатомія травматичної хвороби спинного мозку», «Морфологічні зміни у судинах середнього i великого калібру при висипному тифі», «Морфологічні зміни в судинній системі при скарлатині» (кафедра патологічної анатомії), «Розвиток іннервації серця», «Розвиток та іннервація мигдалин» (кафедра гістології), «До питання про оперативний доступ до локалізованих легеневих захворювань 3 урахуванням чотирьох сегментів анатомії легені», «Лікування залишкових порожнин і бронхіальних свищів після вогнепальних проникаючих поранень грудної клітки», «Сліпі поранення серця і серцевої сорочки», «Клініка і лікування залишкових явищ після вогнепальних пошкоджень довгих трубчастих кісток», «До питання про лікування тривалих незаживаючих виразок після травми», «Гангрена нижніх кінцівок після висипного тифу та ії лікування» (кафедра загальної хірургії), «Історико-філософські погляди О. Кобилянської», «60-ті рр. у спогадах М.А. Антоновича» (кафедра марксизму-ленінізму) та ін ${ }^{10}$.

Науково-дослідні роботи виконували і клініки при ЧДМІ. Так, на 1945-1946 рр. працівники отоларингологічної клініки запланували такі теми науководослідної роботи: «Динаміка процесу об'ємної латералізації придаткових порожнин носа», «Стан придаткових порожнин носа у хворих на туберкульоз за секційним матеріалом», «Антропометрична характеристика черепів вушних хворих ЛОР-клініки ЧДМІ», «Випадок ангіоми нижньої носової раковини», «Лікування незаживаючих завушних трофічних виразок парафіновим пломбуванням», «Казуїстика травм гортані і глотки», «Лікування вушних суб'єктивних шумів антиневротичної етіології» та ін ${ }^{11}$.

Проблема вибору наукової тематики існувала в усій системі охорони здоров'я. Про це свідчить план наукової роботи, затверджений Міністерством охорони здоров'я у січні 1946 р.: кількість тем - 46 та окремо затверджена проблема «Ендемічний зоб на Буковині», яка містила ще 16 тем (всього 62 теми). Основні 3 них: ендемічний зоб на Буковині, гормональна секреція, відновлювальна післявоєнна хірургія, регенерація, охорона материнства і дитинства, рак, сифіліс, гонорея, нейроінфекції, лікування хвороб вуха, горла, носа, синтез сульфідину та ін. До плану наукової роботи інституту на п'ятирічку 19461950 рр. уведено 155 тем, які розподілено з-поміж 9ти проблем. Важливим є той факт, що 5-річний план передбачав написання та захист 62 дисертаційних робіт (16 докторських та 46 кандидатських) ${ }^{12}$. У протоколі № 14 засідання вченої ради ЧДМІ від 30.10 .1946 p. міститься цікава інформація - звіт проф. В.А. Ельберга про свій виступ на засіданні колегії MO3 з питання затвердження плану наукових робіт медичних вишів. Він як представник інституту запропонував 200 наукових тем, розділених на 9 проблем. У той період, коли тоталітарна система вимагала зменшити різноманітність, ця пропозиція викликала дис- 
кусії. Під час обговорення ЧДМІ згадувався в негативному плані, як такий, що «намагаються великою шапкою проблеми прикрити теми, які не належать до тієї проблеми». У своєму слові на колегії проф. В.А. Ельберг наголосив на тому, що «інститут має сміливість представити 68 дисертацій і 200 тем для грунтовної розробки. Можливо, це і багато, проте $\epsilon$ свідчення про ті життєві сили, які є в Чернівецькому інституті і що інститут ці зобов'язання виконає». Відповідь на критику полягала також у ключі голосних надзабов'язань. Думки на колегії розділилися, оскільки на той час не було чітко сформульованої думки про кількісні параметри наукових тем. У результаті дискусії план ЧДМІ був прийнятий комісією, кількість тем дещо скорочено.

На цьому ж засіданні вченої ради ЧДМІ було затверджено 9 проблемних комісій (голови: Є.Р. Цитрицький, В.А. Ельберг, С.П. Закривидорога, О.Ю. Мангейм, Б.П. Александровський, І.Г. Федоров, М.К. Венцківський, Н.М. Шінкерман і С.К. Лобинцев) та склад редколегії для видання наукових праць інституту (Д.С. Ловля, О.Ю. Мангейм, В.А. Ельберг, М.К. Венцківський, І.Г. Федоров, Н.П. Татаренко, М.I. Михалойц, С.М. Савенко, С.К. Лобинцев, Н.М. Шінкерман) ${ }^{\mathbf{1}}$.

Зі звіту ЧДМІ Міністерству охорони здоров’я про науково-дослідну діяльність за 1947 р. дізнаємось про те, що загальний план інституту разом 3 перехідними темами вміщував 120 тем, на 1948 р. - 47 тем. Науковий план включав таку проблематику: «Вивчення ендемічного зобу в Північній Буковині»10 тем; «Венеризм в Північній Буковині» - 4 теми; «Нові методи діагностики, терапії і профілактики» 21 тема; «Питання регуляції життєвих процесів» - 22 теми; «Питання охорони материнства і дитинства" 8 тем; «Патогенез пухлин» - 6 тем; «Санітарні наслідки війни» - 16 тем; «Позапроблемні питання» - 6 тем. 3-поміж цих тем 32 мали теоретичне та експериментальне спрямування й розроблялися силами кількох кафедр (12 - 3 терміном виконання у 1947 р.); 40 - теоретичними та експериментальними дослідженнями загальнонаукового характеру (23 - 3 терміном виконання у 1947 р.); 48 - дисертаційними темами (12 - 3 терміном виконання у 1947 р.). У 1947 р. відсоток виконаних робіт склав $45 \%$. Причинами невиконання плану були: 1) недостатньо продумана наукова тематика у зв'язку з чим бракувало об'єктивних причин для їхнього виконання (апаратури, реактивів); 2) велика кількість запланованих дисертацій i надто жорсткі терміни для їх виконання, проте кафедрами виконано близько 30 незапланованих наукових робіт $^{13}$. Тобто, великий обсяг наукових досліджень був надскладним, план переоцінював реальні можливості інституту, який не мав статусу науководослідного.

Подібна тенденція прослідковувалася і в наступні роки. На 1951 р. ЧДМІ запланував 67 тем, з яких 30 тем 3 терміном виконання у 1951 р. Теми розподілені за такими проблемами: 1. Ендемічний зоб (11 тем); 2. Епідеміологія, мікробіологія і окрема патологія інфекцій (14 тем); 3. Кортико-вісцеральна патологія (12 тем); 4. Серцево-судинна патологія (7 тем); 5. Позапроблемні теми (9 тем); 6. Планування дисертацій (14 тем). Проблема «Ендемічний зоб» була провідною в науковій тематиці ЧДМІ, в її розробці брало участь 9 кафедр. Дві роботи присвячені кровообігу та іннервації щитовидної залози в нормі і патології, 4 теми серцево-судинній системі і морфології крові при зобі, 3 теми - клініці зоба, 2 теми - впливу зоба на дітородні функції жінок та на вагітність, 1 тема - профілактиці і лікуванню зоба. До числа тем з цієї проблематики 2 додалося також 2 кандидатські дисертації ${ }^{14}$. Така тенденція має місце й у 1953 р. - 98 тем (з них 25 з терміном виконання у 1953 р.), та 1954 р. - 104 теми (3 них 47 - 3 терміном виконання у 1953 р.). ${ }^{2}$

Щодо плану дисертаційних робіт, явно завищеного, за першу п'ятирічку він був виконаний на 50 \%. Варто нагадати, що першим співробітником ЧДМІ, який захистив докторську дисертацію був завкафедри хірургії Т.М. Гуляницький («До хірургічного лікування виразкової хвороби шлунка», захищена у 1946 р. у Горьківському медінституті). У 1947 р. було захищено 2 докторських (Є.Р. Цитрицький, Н.П. Татаренко) та 6 кандидатських дисертацій; у 1948 р. - 5 кандидатських дисертацій; у 1949 р. - 3 кандидатських; у 1950 р. - 2 докторські (Я.П. Скляров, Д.С. Четвертак) та 3 кандидатських; у 1951 р. - 12 кандидатських; у 1952 р. - 1 докторська (К.Д. Філатова) та 8 кандидатських; у 1953 р. - 1 докторська (Ф.А. Баштан) та 6 кандидатськ; у 1954 р. - 2 докторських (І.В. Семенов, B.B. Попов) та 13 кандидатських. Таким чином спостерігається позитивна динаміка росту кількості захищених дисертаційних робіт (див. табл. № 2).

Тематика дисертаційних робіт, захищених професорсько-викладацьким складом ЧДМІ за перші 10 років його діяльності (1944-1954 рр.)

\begin{tabular}{|c|c|c|c|c|}
\hline № & $\begin{array}{c}\text { ПІБ, } \\
\text { посада дисертанта }\end{array}$ & Тематика дисертаційних робіт & $\begin{array}{c}\text { Установа, в } \\
\text { якій захищена } \\
\text { робота }\end{array}$ & Рік \\
\hline 1. & $\begin{array}{c}\text { Гуляницький T.М., } \\
\text { завкафедри загальної } \\
\text { хірургії }\end{array}$ & $\begin{array}{c}\text { «До хірургічного лікування виразкової } \\
\text { хвороби» (докторська дисертація) }\end{array}$ & $\begin{array}{c}\text { Горьковський } \\
\text { медінститут }\end{array}$ & 1946 \\
\hline 2. & $\begin{array}{c}\text { Цитрицький Є.P. } \\
\text { завкафедри } \\
\text { факультетської хірургії }\end{array}$ & 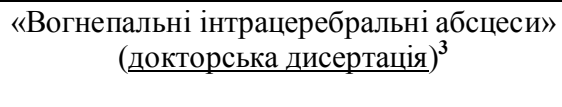 & немає даних & 1947 \\
\hline
\end{tabular}


Бойчук Т., Мойсей А. Організація наукової діяльності...

\begin{tabular}{|c|c|c|c|c|}
\hline 3. & $\begin{array}{c}\text { Татаренко Н.П., } \\
\text { завкафедри } \\
\text { психіатрії } \\
\end{array}$ & $\begin{array}{c}\text { «д психопатології фантомних явищ у свіже } \\
\text { ампутованих» } \\
\text { (докторська дисертація) }\end{array}$ & $\begin{array}{l}\text { Харківський } \\
\text { медінститут }\end{array}$ & $-/ /-$ \\
\hline 4. & $\begin{array}{l}\text { Тіханович І.Ф., } \\
\text { асист. кафедри } \\
\text { очних хвороб }\end{array}$ & $\begin{array}{c}\text { «Око і вагітність» } \\
\text { (кандидатська дисертація) }\end{array}$ & $\begin{array}{c}\text { Київський } \\
\text { медінститут }\end{array}$ & $-1 /-$ \\
\hline 5. & $\begin{array}{l}\text { Лубенський, } \\
\text { асист. кафедри } \\
\text { акушерства і } \\
\text { гінекології }\end{array}$ & $\begin{array}{c}\text { «Взаємовідносини між гормональною секрецією і } \\
\text { мінеральним обміном у вагітних, роділлі та } \\
\text { породіллі» (кандидатська дисертація) }\end{array}$ & $\begin{array}{l}\text { Харківський } \\
\text { медінститут }\end{array}$ & $-1 /-$ \\
\hline 6. & $\begin{array}{c}\text { Рибалкін П.Е., } \\
\text { асист. кафедри } \\
\text { загальної хірургї̈ }\end{array}$ & $\begin{array}{c}\text { «Ендемічний зоб у Північній Буковині» } \\
\text { (кандидатська дисертація) }\end{array}$ & $\begin{array}{l}\text { Центральний } \\
\text { інститут } \\
\text { вдосконалення } \\
\text { лікарів } \\
\text { (Москва) }\end{array}$ & $-/ /-$ \\
\hline 7. & $\begin{array}{l}\text { Епельман М.Д., } \\
\text { асист. кафедри } \\
\text { нервових хвороб } \\
\end{array}$ & $\begin{array}{c}\text { «Неврологія висипного тифу» } \\
\text { (кандидатська дисертація) }\end{array}$ & $\begin{array}{c}\text { Київський } \\
\text { медінститут }\end{array}$ & $-/ /-$ \\
\hline 8. & $\begin{array}{c}\text { Рузінова Ю.Г., } \\
\text { асист. кафедри } \\
\text { нервових хвороб }\end{array}$ & $\begin{array}{c}\text { «ервинні розсіяні енцефаломієліти» } \\
\text { (кандидатська дисертація) }\end{array}$ & $\begin{array}{c}\text { Київський } \\
\text { медінститут }\end{array}$ & $-/ /-$ \\
\hline 9. & $\begin{array}{c}\text { Пекарський М.Д., } \\
\text { завкафедри } \\
\text { інфекційних } \\
\text { хвороб }\end{array}$ & $\begin{array}{c}\text { «Клініка туляремії» } \\
\text { (кандидатська дисертація) }\end{array}$ & $\begin{array}{l}\text { Академія наук } \\
\text { СРСР }\end{array}$ & $-/ /-$ \\
\hline 10. & $\begin{array}{l}\text { Дорошкевич, } \\
\text { асист. кафедри } \\
\text { факультетської } \\
\text { хірургії }\end{array}$ & $\begin{array}{c}\text { «Напівколоїдна емульсія при лікуванні гнійних } \\
\text { ран» (кандидатська дисертація) }\end{array}$ & $\begin{array}{c}\text { Центральний } \\
\text { інститут вдос- } \\
\text { коналення лі- } \\
\text { карів (Москва) }\end{array}$ & 1948 \\
\hline 11. & $\begin{array}{c}\text { Бзинко, } \\
\text { асист. кафедри } \\
\text { загальної хірургії }\end{array}$ & $\begin{array}{c}\text { «Клініка ендартеріїтів при висипному тифі» } \\
\text { (кандидатська дисертація) }\end{array}$ & $\begin{array}{c}\text { Горьківський } \\
\text { медінститут }\end{array}$ & $-/ /-$ \\
\hline 12. & $\begin{array}{c}\text { Кудрявцев, } \\
\text { асист. кафедри } \\
\text { загальної хірургії }\end{array}$ & $\begin{array}{l}\text { «Лікування хронічних остеомієлітів» } \\
\text { (кандидатська дисертація) }\end{array}$ & $\begin{array}{c}\text { Горьківський } \\
\text { медінститут }\end{array}$ & $-/ /-$ \\
\hline 13. & $\begin{array}{c}\text { Фішер Г.Г., } \\
\text { асист. кафедри но- } \\
\text { рмальної анатомії }\end{array}$ & $\begin{array}{c}\text { «До питання про клініку та лікування травматичного } \\
\text { пневмотораксу» } \\
\text { (кандидатська дисертація) }\end{array}$ & $\begin{array}{c}\text { Одеський } \\
\text { медінститут }\end{array}$ & $-/ /-$ \\
\hline 14. & $\begin{array}{l}\text { Сівер П.Я., } \\
\text { доцент кафедри } \\
\text { біохімії }\end{array}$ & $\begin{array}{c}\text { «Фазові співвідношення сірки у змішаних бінарних } \\
\text { органічних розчинах» } \\
\text { (кандидатська дисертація) }\end{array}$ & $\begin{array}{l}\text { Московський } \\
\text { фізико-хіміч- } \\
\text { ний інститут } \\
\text { ім. Л. Карпова }\end{array}$ & $-/ /-$ \\
\hline 15. & $\begin{array}{c}\text { Ловля Д.С., } \\
\text { директор ЧДМІ }\end{array}$ & $\begin{array}{c}\text { «едико-санітарні організації у боротьбі за ліквіда- } \\
\text { цію висипного тифу у Чкаловській, Харківській та } \\
\text { Чернівецькій областях у роки Великої Вітчизняної } \\
\text { війни 1941-1945 рр. та післявоєнні } \\
\text { роки» (кандидатська дисертація) }\end{array}$ & $\begin{array}{c}\text { Київський ме- } \\
\text { дінститут }\end{array}$ & 1949 \\
\hline 16. & $\begin{array}{l}\text { Авербух С.Л., } \\
\text { асист. кафедри } \\
\text { очних хвороб }\end{array}$ & $\begin{array}{c}\text { «Клінічні спостереження над лікувальною дією суб- } \\
\text { кон'юнктивальних імплантацій кетгута при туберку- } \\
\text { льозних та скрофульозних захворювань } \\
\text { ока» (кандидатська дисертація) }\end{array}$ & $\begin{array}{c}\text { Київський } \\
\text { медінститут }\end{array}$ & $-/ /-$ \\
\hline 17. & $\begin{array}{l}\text { Гордієнко В.І., } \\
\text { асист. кафедри } \\
\text { госпіт. хірургії }\end{array}$ & $\begin{array}{c}\text { «Діагностичне значення досліджень суглобової ріди- } \\
\text { ни при травматичних пошкодженнях колінного } \\
\text { суглобу» (кандидатська дисертація) }\end{array}$ & $\begin{array}{c}\text { Київський } \\
\text { медінститут }\end{array}$ & $-/ /-$ \\
\hline 18. & $\begin{array}{c}\text { Скляров Я.П., } \\
\text { завкафедри } \\
\text { фізіології } \\
\end{array}$ & $\begin{array}{c}\text { «Матеріали до аналізу секреторних функцій шлунко- } \\
\text { вих залоз при тривалому їх збудженні» } \\
\text { (докторська дисертація) }\end{array}$ & $\begin{array}{c}\text { Київський } \\
\text { медінститут }\end{array}$ & 1950 \\
\hline 19. & $\begin{array}{c}\text { Четвертак Д.С., } \\
\text { завкафедри } \\
\text { патофізіології } \\
\end{array}$ & $\begin{array}{c}\text { «Роль центральної нервової системи в механізмах } \\
\text { гемотрансфузійних реакцій» } \\
\text { (докторська дисертація) }\end{array}$ & $\begin{array}{l}\text { Казахський } \\
\text { медінститут }\end{array}$ & $-/ /-$ \\
\hline
\end{tabular}




\begin{tabular}{|c|c|c|c|c|}
\hline 20. & $\begin{array}{c}\text { Аношкін Т.А., } \\
\text { асист. кафедри } \\
\text { нормальної анатомії }\end{array}$ & $\begin{array}{c}\text { «Анатомо-топографічне обгрунтування за- } \\
\text { кономірностей розповсюдження гнійних } \\
\text { запальних процесів при травматичному по- } \\
\text { шкодженні променево-зап'ясткового } \\
\text { суглобу» (кандидатська дисертація) }\end{array}$ & $\begin{array}{l}\text { Дніпропетровський } \\
\text { медінститут }\end{array}$ & $-/ /-$ \\
\hline 21. & $\begin{array}{c}\text { Гудзенко П.Н., } \\
\text { доц. кафедри педіатрії }\end{array}$ & $\begin{array}{c}\text { «Хронічна дизентерія» } \\
\text { (кандидатська дисертація) }\end{array}$ & $\begin{array}{c}\text { Київський } \\
\text { медінститут }\end{array}$ & $-/ /-$ \\
\hline 22. & $\begin{array}{c}\text { Любовська П.І., } \\
\text { асист. кафедри } \\
\text { патофізіології }\end{array}$ & $\begin{array}{c}\text { «Обмін глютатіона і цукру між кров'ю і } \\
\text { тканинами при збудженні та гальмуванні } \\
\text { нервової системи» } \\
\text { (кандидатська дисертація) } \\
\end{array}$ & $\begin{array}{l}\text { Львівський } \\
\text { медінститут }\end{array}$ & $-/ /-$ \\
\hline 23. & $\begin{array}{c}\text { Дорошкевич А.Н., } \\
\text { асист. кафедри мікробі- } \\
\text { ології }\end{array}$ & $\begin{array}{c}\text { «Мінливість мікробів дизентерійної групи» } \\
\text { (кандидатська дисертація) }\end{array}$ & $\begin{array}{c}\text { Центральний інсти- } \\
\text { тут вдосконалення } \\
\text { лікарів (Москва) }\end{array}$ & 1951 \\
\hline 24. & $\begin{array}{c}\text { Рибас I.I., } \\
\text { доц. кафедри } \\
\text { мікробіології }\end{array}$ & $\begin{array}{c}\text { «ласифікація та мінливість бактерій миша- } \\
\text { чого тифу» (кандидатська дисертація) }\end{array}$ & $\begin{array}{l}\text { Дніпропетров. } \\
\text { медінститут }\end{array}$ & $-/ /-$ \\
\hline 25. & $\begin{array}{c}\text { Шевчук І.А., } \\
\text { завкафедри } \\
\text { гістології } \\
\end{array}$ & $\begin{array}{c}\text { «Вікові особливості гістологічної побудови } \\
\text { підшлункової залози людини» } \\
\text { (кандидатська дисертація) }\end{array}$ & немає даних & $-/ /-$ \\
\hline 26. & $\begin{array}{c}\text { Василенко А.Г., } \\
\text { асист. кафедри } \\
\text { мікробіології } \\
\end{array}$ & $\begin{array}{c}\text { «Антагонізм спорових мікробів анаеробів і } \\
\text { направлена мінливість» } \\
\text { (кандидатська дисертація) }\end{array}$ & $\begin{array}{l}\text { Харківський } \\
\text { медінститут }\end{array}$ & $-/ /-$ \\
\hline 27. & $\begin{array}{c}\text { Степанова А.П., } \\
\text { асист. кафедри } \\
\text { гігієни } \\
\end{array}$ & $\begin{array}{c}\text { «Про механізм дії ультрафіолетових проме- } \\
\text { нів» } \\
\text { (кандидатська дисертація) }\end{array}$ & $\begin{array}{l}\text { Харківський } \\
\text { медінститут }\end{array}$ & $-/ /-$ \\
\hline 28. & $\begin{array}{c}\text { Малий Д.П., } \\
\text { завкафедри } \\
\text { марксизму-ленінізму }\end{array}$ & $\begin{array}{c}\text { «Боротьба трудящих Північної Буковини } \\
\text { проти румунських імперіалістів за } \\
\text { національне та } \\
\text { соціальне звільнення возз'єднання з Радян- } \\
\text { ською Україною» (кандидатська дисертація) }\end{array}$ & $\begin{array}{l}\text { Московський } \\
\text { університет }\end{array}$ & $-/ /-$ \\
\hline 29. & $\begin{array}{c}\text { Поляк Р.І., } \\
\text { асист. кафедри топана- } \\
\text { томії } \\
\end{array}$ & $\begin{array}{l}\text { «Шляхи розповсюдження гнійних запальних } \\
\text { процесів при вогнепальних пораненнях лік- } \\
\text { тьового суглобу» (кандидатська дисертація) }\end{array}$ & $\begin{array}{l}\text { Кишинівський } \\
\text { медінститут }\end{array}$ & $-/ /-$ \\
\hline 30. & $\begin{array}{l}\text { Полотай В.А., } \\
\text { асист. кафедри } \\
\text { гістології } \\
\end{array}$ & $\begin{array}{c}\text { «Регенерація периферійних нервів в умовах } \\
\text { автогенного венозного футляра» } \\
\text { (кандидатська дисертація) }\end{array}$ & $\begin{array}{c}\text { Київський } \\
\text { медінститут }\end{array}$ & $-/ /-$ \\
\hline 31. & $\begin{array}{l}\text { Яковлева А., } \\
\text { асист. кафедри } \\
\text { біології }\end{array}$ & $\begin{array}{c}\text { «Панцирні молюски морів СРСР» } \\
\text { (кандидатська дисертація) }\end{array}$ & $\begin{array}{c}\text { Зоологічний } \\
\text { інститут АН СРСР }\end{array}$ & $-/ /-$ \\
\hline 32. & $\begin{array}{c}\text { Архіпова В.В., } \\
\text { асист. кафедри } \\
\text { педіатрії } \\
\end{array}$ & $\begin{array}{c}\text { «Лямбліоз у дітей» } \\
\text { (кандидатська дисертація) }\end{array}$ & $\begin{array}{c}\text { Київський } \\
\text { медінститут }\end{array}$ & $-/ /-$ \\
\hline 33. & $\begin{array}{c}\text { Борима Т.В., } \\
\text { доц. кафедри } \\
\text { акушерства і } \\
\text { гінекології }\end{array}$ & $\begin{array}{c}\text { «Аргірофільна речовина плаценти } \\
\text { в нормі і патологія» } \\
\text { (кандидатська дисертація) }\end{array}$ & $\begin{array}{c}\text { Київський } \\
\text { медінститут }\end{array}$ & $-/ /-$ \\
\hline 34. & $\begin{array}{c}\text { Лозинський М.А., } \\
\text { асист. кафедри } \\
\text { акушерства і гінекології } \\
\end{array}$ & $\begin{array}{c}\text { «Танинна терапія в гінекології» } \\
\text { (кандидатська дисертація) }\end{array}$ & $\begin{array}{l}\text { Львівський } \\
\text { медінститут }\end{array}$ & $-/ /-$ \\
\hline 35. & $\begin{array}{c}\text { Філатова К.Д., } \\
\text { завкафедри анатоміі }\end{array}$ & $\begin{array}{c}\text { «Макро-мікроскопія хрящового остова бро- } \\
\text { нхів людини і тварин» } \\
\text { (докторська дисертація) } \\
\end{array}$ & $\begin{array}{l}\text { Харківський } \\
\text { медінститут }\end{array}$ & 1952 \\
\hline 36. & $\begin{array}{c}\text { Роман Л.І., } \\
\text { асист. кафедри } \\
\text { факультетської } \\
\text { хірургії } \\
\end{array}$ & $\begin{array}{c}\text { «Плевральні ускладнення у поранених у } \\
\text { груди в армійському і фронтовому районах» } \\
\text { (кандидатська дисертація) }\end{array}$ & $\begin{array}{l}\text { Центральний інсти- } \\
\text { тут вдосконалення } \\
\text { лікарів (Москва) }\end{array}$ & $-/ /-$ \\
\hline 37. & $\begin{array}{l}\text { Сомова А.Г., } \\
\text { асист. кафедри } \\
\text { мікробіології }\end{array}$ & $\begin{array}{c}\text { «Парааглютінація кишкової палички - пер- } \\
\text { ший етап направленної мінливості» } \\
\text { (кандидатська дисертація) }\end{array}$ & $\begin{array}{l}\text { Ростовський } \\
\text { медінститут }\end{array}$ & $-/ /-$ \\
\hline
\end{tabular}


Бойчук Т., Мойсей А. Організачія наукової діяльності...

\begin{tabular}{|c|c|c|c|c|}
\hline 38. & $\begin{array}{c}\text { Закривидорога 3.С., } \\
\text { асист. кафедри } \\
\text { патофізіології }\end{array}$ & $\begin{array}{c}\text { «До фармакології та експериментальної фармако- } \\
\text { терапії терпентину (живиці) з Буковинської } \\
\text { піхти» (кандидатська дисертація) }\end{array}$ & $\begin{array}{l}\text { Львівський } \\
\text { медінститут }\end{array}$ & $-/ /-$ \\
\hline 39. & $\begin{array}{l}\text { Бухарович М.Н., } \\
\text { асист. кафедри } \\
\text { шкірних хвороб }\end{array}$ & $\begin{array}{c}\text { «Дослідження спинномозкової рідини у хворих } \\
\text { на сифіліс та організація їх комплексного } \\
\text { дослідження після закінчення лікування» } \\
\text { (кандидатська дисертація) }\end{array}$ & $\begin{array}{c}\text { Центральний } \\
\text { інститут вдоско- } \\
\text { налення лікарів } \\
\text { (Москва) }\end{array}$ & $-/ /-$ \\
\hline 40. & $\begin{array}{l}\text { Ліпсіц Д.В., } \\
\text { асист. кафедри } \\
\text { біохімії }\end{array}$ & $\begin{array}{c}\text { «Окислювально-відновлювальні процеси у кише- } \\
\text { чнику у хворих на черевний тиф» } \\
\text { (кандидатська дисертація) }\end{array}$ & $\begin{array}{c}\text { Київський } \\
\text { медінститут }\end{array}$ & $-/ /-$ \\
\hline 41. & $\begin{array}{c}\text { Лекер Х.Я., } \\
\text { завкафедри іноз. мов }\end{array}$ & $\begin{array}{c}\text { «Квінтіліан, як критик римської } \\
\text { літератури» } \\
\text { (кандидатська дисертація) }\end{array}$ & $\begin{array}{l}\text { Московський } \\
\text { університет }\end{array}$ & $-/ /-$ \\
\hline 42. & Савіних I.I. & $\begin{array}{l}\text { «Висипнотифозні гангрени» } \\
\text { (кандидатська дисертація) }\end{array}$ & $\begin{array}{c}\text { Київський } \\
\text { медінститут }\end{array}$ & $-/ /-$ \\
\hline 43. & $\begin{array}{c}\text { Макоха Н.С., } \\
\text { асист. кафедри } \\
\text { загальної хірургії }\end{array}$ & $\begin{array}{c}\text { «Амортизаційно-екстензійний метод } \\
\text { лікування переломів» } \\
\text { (кандидатська дисертація) }\end{array}$ & $\begin{array}{c}\text { Центральний } \\
\text { інститут вдоско- } \\
\text { налення лікарів } \\
\text { (Москва) }\end{array}$ & $-/ /-$ \\
\hline 44. & $\begin{array}{c}\text { Баштан Ф.А., } \\
\text { завкафедри гігієни }\end{array}$ & $\begin{array}{c}\text { «Роль гігієнічних факторів в етіології ендемічно- } \\
\text { го зоба» (докторська дисертація) }\end{array}$ & $\begin{array}{c}\text { Київський } \\
\text { медінститут }\end{array}$ & 1953 \\
\hline 45. & $\begin{array}{c}\text { Колачов А.А., } \\
\text { завкафедри } \\
\text { проп. терапії }\end{array}$ & $\begin{array}{c}\text { «Кримська геморагічна лихоманка» } \\
\text { (кандидатська дисертація) }\end{array}$ & $\begin{array}{c}\text { Київський } \\
\text { медінститут }\end{array}$ & $-/ /-$ \\
\hline 46. & $\begin{array}{c}\text { Троян Г.А., } \\
\text { асист. кафедри } \\
\text { шкірних хвороб }\end{array}$ & $\begin{array}{c}\text { «ерматомікози Чернівецької області» } \\
\text { (кандидатська дисертація) }\end{array}$ & $\begin{array}{l}\text { Кишинівський } \\
\text { медінститут }\end{array}$ & $-/ /-$ \\
\hline 47. & $\begin{array}{l}\text { Жовновата О.Д., } \\
\text { асист. кафедри } \\
\text { фізіології }\end{array}$ & $\begin{array}{c}\text { «Механізми кореляції функцій шлунку та виділь- } \\
\text { ні функції нирок» } \\
\text { (кандидатська дисертація) }\end{array}$ & $\begin{array}{l}\text { Харківський } \\
\text { медінститут }\end{array}$ & $-/ /-$ \\
\hline 48. & $\begin{array}{c}\text { Морозов М.С., } \\
\text { завкафедри фізики }\end{array}$ & $\begin{array}{c}\text { «Вплив напруженого стану на якість } \\
\text { поршневих кілець» } \\
\text { (кандидатська дисертація) }\end{array}$ & $\begin{array}{c}\text { Горьківський } \\
\text { політехнічний } \\
\text { інститут }\end{array}$ & $-/ /-$ \\
\hline 49. & $\begin{array}{c}\text { Дунаєва Л.П., } \\
\text { асист. кафедри } \\
\text { педіатрії }\end{array}$ & $\begin{array}{c}\text { «Кишковий спірохетоз і його роль при } \\
\text { хронічній дизентерії» } \\
\text { (кандидатська дисертація) }\end{array}$ & $\begin{array}{l}\text { Львівський } \\
\text { медінститут }\end{array}$ & $-/ /-$ \\
\hline 50. & $\begin{array}{l}\text { Лопушанський A.I., } \\
\text { завкафедри } \\
\text { загальної хімії }\end{array}$ & $\begin{array}{c}\text { «Вплив сечовини на окислювально- } \\
\text { відновлювальні процеси в регенеруючій ткани- } \\
\text { ні» (кандидатська дисертація) }\end{array}$ & $\begin{array}{c}\text { Київський } \\
\text { медінститут }\end{array}$ & $-/ /-$ \\
\hline 51. & $\begin{array}{c}\text { Семенов І.В., } \\
\text { завкафедри фізіології }\end{array}$ & $\begin{array}{c}\text { «Зміна температури головного мозку та їх виник- } \\
\text { нення в нормі та патології» } \\
\text { (докторська дисертація) }\end{array}$ & $\begin{array}{c}\text { Київський } \\
\text { медінститут }\end{array}$ & 1954 \\
\hline 52. & $\begin{array}{c}\text { Попов В.В., } \\
\text { завкафедри загальної } \\
\text { хірургії }\end{array}$ & $\begin{array}{c}\text { «ервинний рак жовчного міхура і } \\
\text { позапечінкових жовчних проток» } \\
\text { (докторська дисертація) }\end{array}$ & $\begin{array}{l}\text { Ленінградський } \\
\text { медінститут }\end{array}$ & $-/ /-$ \\
\hline 53. & $\begin{array}{l}\text { Чуракова С.А., } \\
\text { асист. кафедри гос- } \\
\text { піт. терапії }\end{array}$ & $\begin{array}{c}\text { «Клініка початкових форм ендемічного зоба на } \\
\text { Буковині» } \\
\text { (кандидатська дисертація) }\end{array}$ & $\begin{array}{l}\text { Львівський } \\
\text { медінститут }\end{array}$ & $-/ /-$ \\
\hline 54. & $\begin{array}{l}\text { Крічін Я.Д., } \\
\text { асист. кафедри } \\
\text { госпіт. терапії }\end{array}$ & $\begin{array}{c}\text { «Меркузал у клініці внутрішніх хвороб» } \\
\text { (кандидатська дисертація) }\end{array}$ & $\begin{array}{c}\text { Київський } \\
\text { медінститут }\end{array}$ & $-/ /-$ \\
\hline 55. & $\begin{array}{l}\text { Сєргєєв Г.Г., } \\
\text { асист. кафедри } \\
\text { госпіт. терапії }\end{array}$ & $\begin{array}{c}\text { «Електрокардіографічні дані спортсменів різної } \\
\text { тренованості при фізичних } \\
\text { напруженнях на витривалість» } \\
\text { (кандидатська дисертація) } \\
\end{array}$ & $\begin{array}{l}\text { Львівський } \\
\text { медінститут }\end{array}$ & $-/ /-$ \\
\hline 56. & $\begin{array}{l}\text { Невська Т.Л., } \\
\text { асист. кафедри } \\
\text { фармакології }\end{array}$ & $\begin{array}{c}\text { «До питання вікової чутливості організму до де- } \\
\text { яких ліків та отрут (морфіну, } \\
\text { новокаїну, гексеналу, строфантіну і } \\
\text { стріхніну)» (кандидатська дисертація) }\end{array}$ & $\begin{array}{l}\text { Львівський } \\
\text { медінститут }\end{array}$ & $-/ /-$ \\
\hline
\end{tabular}




\begin{tabular}{|c|c|c|c|c|}
\hline 57. & $\begin{array}{l}\text { Іванова Н.Ф., } \\
\text { асист. кафедри } \\
\text { топанатомії }\end{array}$ & $\begin{array}{c}\text { «Шляхи розповсюдження гнійних } \\
\text { запалювальних процесів при пораненнях } \\
\text { гомілковостопного суглобу» } \\
\text { (кандидатська дисертація) }\end{array}$ & $\begin{array}{l}\text { Новосибірський } \\
\text { медінститут }\end{array}$ & $-/ /-$ \\
\hline 58. & $\begin{array}{l}\text { Піскуненко І.Ф., } \\
\text { викл. кафедри } \\
\text { маркс.-ленінзму }\end{array}$ & $\begin{array}{c}\text { «Доходи колгоспів Західних областей } \\
\text { УРСР» (кандидатська дисертація) }\end{array}$ & $\begin{array}{c}\text { Київський } \\
\text { медінститут }\end{array}$ & $-/ /-$ \\
\hline 59. & $\begin{array}{l}\text { Водовозов А.М., } \\
\text { асист. кафедри } \\
\text { очних хвороб }\end{array}$ & $\begin{array}{c}\text { «Продовження дії пеніциліну при місцевому } \\
\text { застосуванню в офтальмології» } \\
\text { (кандидатська дисертація) }\end{array}$ & $\begin{array}{c}\text { Київський } \\
\text { медінститут }\end{array}$ & $-1 /-$ \\
\hline 60. & $\begin{array}{c}\text { Петров Ю.Л., } \\
\text { асист. кафедри } \\
\text { фізіології }\end{array}$ & $\begin{array}{c}\text { «Кістковий мозок, як депо крові» } \\
\text { (кандидатська дисертація) }\end{array}$ & $\begin{array}{l}\text { Львівський } \\
\text { медінститут }\end{array}$ & $-/ /-$ \\
\hline 61. & $\begin{array}{c}\text { Довгань 3.В., } \\
\text { асист. кафедри } \\
\text { фізіології }\end{array}$ & $\begin{array}{c}\text { «Нервовий механізм збудження } \\
\text { шлункових залоз» } \\
\text { (кандидатська дисертація) }\end{array}$ & $\begin{array}{l}\text { Львівський } \\
\text { медінститут }\end{array}$ & $-/ /-$ \\
\hline 62. & $\begin{array}{l}\text { Головін Д.І., } \\
\text { асист. кафедри } \\
\text { гігієни } \\
\end{array}$ & $\begin{array}{c}\text { «Роль санітарно-побутових факторів в етіо- } \\
\text { логії ендемічного зоба» } \\
\text { (кандидатська дисертація) }\end{array}$ & $\begin{array}{c}\text { Київський } \\
\text { медінститут }\end{array}$ & $-/ /-$ \\
\hline 63. & $\begin{array}{c}\text { Касько Ю.С., } \\
\text { асист. кафедри шкірно- } \\
\text { венеричних хвороб }\end{array}$ & $\begin{array}{c}\text { «Лікування хворих на туберкульоз шкіри } \\
\text { вітаміном Д2 у поєднанні з поверхневим } \\
\text { руйнуванням та додатковим ультрафіолето- } \\
\text { вим випромінюванням шкірно- } \\
\text { туберкульозних вогнищ» } \\
\text { (кандидатська дисертація) }\end{array}$ & $\begin{array}{l}\text { Львівський } \\
\text { медінститут }\end{array}$ & $-1 /-$ \\
\hline 64. & $\begin{array}{c}\text { Донігевич М.I., } \\
\text { асист. кафедри аку- } \\
\text { шерства і гінекології }\end{array}$ & $\begin{array}{c}\text { «Клінічний перебіг родів при психопрофі- } \\
\text { лактичному знеболюванню» } \\
\text { (кандидатська дисертація) }\end{array}$ & $\begin{array}{l}\text { Кишинівський } \\
\text { медінститут }\end{array}$ & $-/ /-$ \\
\hline 65. & $\begin{array}{c}\text { Кантор А.А., } \\
\text { асист. кафедри } \\
\text { отоларингології } \\
\end{array}$ & $\begin{array}{c}\text { «ластика шкірно-заглибним клаптем при } \\
\text { радикальній операції вуха» } \\
\text { (кандидатська дисертація) }\end{array}$ & $\begin{array}{l}\text { Львівський } \\
\text { медінститут }\end{array}$ & $-/ /-$ \\
\hline
\end{tabular}

3 таблиці № 2 видно, що до виконання дисертаційних робіт включилося понад 80 \% кафедр інституту, решта були у стані планування. Найбільш активними виявились у цьому плані співробітники кафедр загальної хірургії (6), фізіології (5), акушерства та гінекології (4), мікробіології (4), факультетської хірургії (3), нормальної анатомії (3), очних хвороб (3), патофізіології (3), педіатрії (3), гігієни (3), госпітальної терапії (3), нервових хвороб (2), інфекційних хвороб (2), біохімії (2), гістології (2), марксизму-ленінізму (2), топографічної анатомії (2), шкірних хвороб (2), психіатрії (1), госпітальної хірургії (1), біології (1), іноземних мов (1), пропедевтичної терапії (1), фізики (1), загальної хімії (1), фармакології (1), шкірновенеричних хвороб (1), отоларингології (1).

Дослідницька діяльність науковців Інституту знаходила своє відображення в публікаціях їі результатів в монографіях та збірниках наукових праць. Для кращого розуміння тематики пошукової роботи, наукових інтересів співробітників різних кафедр наведемо перелік перших монографій та збірників наукових праць, виданих в цей період.

Монографії:

Венцківський М.К. Рак матки. - Київ: Медиздат Украины, 1946. - 48 с.

Венцківський М.К. Мати і дитина. - К.: Медиздат Украины, 1946.

Новіков М.П. Вторинна кровотеча. - К., 1947.

Рапопорт М.Ю. Про механізм сечогінної дії мер- кузалу. - Чернівці: «Рад. Буковина», 1948. - 88 с. 3 діагр.

Щупак Н.Б. Хвороба Боткіна / 3 передм. акад. Н.Д. Стражеско. - К.: Госмедиздат УССР, 1948. - 72 c.

Осіпов Б.К. Остеомієліт та його лікування. На допомогу дільничному лікарю. - М.: МИД СССР, 1949. - 39 c.

Осіпов Б.К. Нариси з хірургії органів грудної порожнини. - М.: МИД СССР, 1949.

Каліна Г.П. Мінливість патогенних мікроорганізмів. - К.: Госмедиздат УССР, 1949. - 156 с.: іл.

Каліна Г.П. Вегетативна гібридизація та спрямована мінливість бактерії. - К.: Госмедиздат УССР, 1952. $-304 \mathrm{c}$.

Щупак Н.Б. Ламбліоз кишечника и жовчних шляхів. Видання 2-е доопр. і доп. - К.: Госмедиздат УССР, 1952, -96 с.: іл.

Яковлева А.М. Панцерні моллюски морів СРСР. М.-Л.: Академия Наук СССР, 1952. - 108 с.: іл.

Каліна Г.П. Розвиток мікробних клітин 3 доклітинної речовини. - К.: Госмедиздат УССР, 1954. 475 с.: іл.

Збірники наукових праць:

«Реактивність організму під час збудження та гальмування». Збірник робіт кафедри патофізіології / за ред. І.Г. Федорова. - Чернівці, 1948. - 102 с.: іл.

Вчені записки Чернівецького державного медичного інституту. - Чернівці, 1949. - Т. 1. - 163 с. 
Збірник праць Чернівецького державного медичного інституту / Під ред. Н.Б. Маньковського, Г.П. Каліни, Я.П. Склярова. - Київ: Госмедиздат УРСР, 1954. - 154 с. Наукова сесія Чернівецького державного медичного інституту, присвячена 10-річчю існування інституту (1944-1954 рр.). Тези доповідей. Київ: Госмедиздат УРСР, 1954. - 96 с.

Науковці ЧДМІ друкували свої матеріали у відомих на той час медичних журналах та збірниках наукових праць: «Антибіотики», «Аптечна справа» («Аптечное дело»), «Біохімія», «Бюлетень експериментальної біології та медицини», «Військова медицина у Великій Вітчизняній Війні», «Військовий медичний журнал», «Вісник венерології та дерматології», «Вісник оториноларингології», «Вісник офтальмології», «Гігієна і санітарія», «Доповіді Академії наук СРСР», «Експериментальна хірургія», «Журнал вищої нервової діяльності», «Журнал фізичної хімії», «Клінічна медицина», «Лабораторна справа», «Лікарська справа» («Врачебное дело»), «Медична паразитологія та паразитарні хвороби», Мікробіологія», «Невропатологія і психіатрія», «Новий хірургічний архів», «Офтальмологічний журнал», «Педіатрія», «Педіатрія, акушерство і гінекологія», «Питання медичної хімії», «Питання нейрохірургії», «Питання фізіології», «Природа», «Проблеми паразитології», «Медична паразитологія та паразитарні хвороби», «Радянська медицина», «Терапевтичний архів», «Український біохімічний журнал», «Хірургія» та ін. Їхні роботи знаходимо у збірниках праць відомих наукових інституцій, як-от: Інституту мікробіології, Українського психоневрологічного інституту тощо. Саме в таких роботах провідні науковці ЧДМІ оприлюднювали результати своїх досліджень чи винаходів. Зокрема, особливості винаходів та результати своїх нововведень проф. Б.Л. Радзіховський подав у низці праць, як-от: «Блефоростат нової конструкції» (Вісник офтальмології. - 1950. - № 6. - С. 39-40), «Вакуумний тонометр» (Вісник офтальмології. 1951. - № 2. - С. 37-39), «Очний пульс» (Офтальмологічний журнал. - 1953. - № 2. С. 104-109), «Нова конструкція пінцета автора для накладення роговичних швів» (Офталь мологічний журнал. - 1951. - № 3. - М. 152-153), проф. А.А. Троїцький - «Пеніцилін-новокаїнова блокада при гнійних запаленнях» (Радянська медицина. - 1953. - № 1. - С. 13-15), проф. Ф.А. Баштан «Прилад для визначення миш'яку» (Врачебное дело. - 1949. - № 7. - С. 629-632) та ін.

Так, за 10 років роботи ЧДМІ виконано близько 500 наукових робіт.

Упродовж перших 10 років діяльності ЧДМІ організовано й проведено понад 20 наукових конференцій, 3-поміж яких варто відзначити конференцію 3 мінливості мікробів (25.09.1948), присвячену ендемічному зобу (30-31.10.1948), Х Наукову конференцію ЧДМІ за підсумками науково-дослідної роботи у 1948 році (02.1949), присвячену питанням антибіотиків (7-8.01.1951), «Павловські читання» (1-16.11.1951) та ін. Професорсько-викладацький склад брав активну участь у роботі наукових товариств (Єдиного медичного товариства; Отоларингологічного, Товарист- ва фізіологів тощо), з"їздів біохіміків, фізіологів, хірургів, акушерів та гінекологів, ортопедів тощо.

Аспірантура та клінічна ординатура. У 1945 році Міністерство охорони здоров'я не надало ЧДМІ жодного аспіранта та клінічного ординатора. Вже у 1946-1947 н. р. в інституті числиться один штатний аспірант на кафедрі нормальної анатомії і 13 клінічних ординаторів ${ }^{15}$. Першим зарахованим аспірантом ЧДМІ 1 серпня 1946 року став Т.А. Аношкін ${ }^{4}$. Відомо, що аспірант був закріплений за кафедрою нормальної анатомії та паралельно працював на посаді асистента цієї ж кафедри. Після закінчення другого року навчання в аспірантурі (кандидатською дисертацією мав керувати доктор наук) MO3 УРСР дозволило прикріпити А.Т. Аношкіна для керівництва дисертацією до д. мед. н., проф., завкафедри нормальної анатомії Дніпропетровського медінституту M.M. Тростанецького. Пізніше був переведений до Дніпропетровського медінституту. Дисертаційну роботу на тему «Анатомо-топографічне обгрунтування закономірностей розповсюдження гнійних запальних процесів при травматичному пошкодженні променево-зап'ясткового суглобу» захищено у 1950 році.

Протягом 1946-1947 н. р. на кафедрі патофізіології зарахований ще один аспірант (керівник - проф. І.Г. Федоров), однак за вказівкою МО3 він був переведений до Львівського медінституту. У 1946-1951 pр. за ЧДМІ числився лише один аспірант, у 19511952 н. р. кількість аспірантів зростає до чотирьох. Із щорічних звітів ЧДМІ відомо, що навчання в аспірантурі було досить проблемним для інституту ${ }^{16} .20$ квітня 1951 року проведено першу наукову конференцію аспірантів та клінічних ординаторів ${ }^{17}$.

Перші два клінічні ординатори зараховані 1 серпня 1946 року, ще 9 - з березня 1947 року, 1 - з липня 1947 року, 1 - завершував ординатуру (переведений із Харківського медінституту). Ординаторів зараховано на кафедри факультетської терапії (2), госпітальної терапії (1), факультетської хірургії (3), госпітальної хірургії (1), шкірно-венеричних хвороб (2), інфекційних хвороб (1), педіатрії (1), акушерства та гінекології (2). Якщо у 1947-1950 рр. кількість клінічних ординаторів зменшилась до 10 (у 1947-1948 н. р. - 11 ординаторів), то вже у звітах за 1950-1951 н. р. та 1951-1952 н. р. подається про збільшення їхньої кількості до 15 та 19 відповідно ${ }^{18}$. Відомо, що з 15 ординаторів, які навчалися у 1950-1951 н. р., десятеро були випускниками ЧДМІ ${ }^{19}$. Низку робіт клінічних ординаторів вже в перші роки їх навчання відзначено викладачами вишу, наприклад, праця ординатора Ю.С. Касько ${ }^{5}$ «Досвід роботи вензагону за матеріалами обстеження Кельменецького району» (керівник доц. М.Г. Безюк) - 1946-1947 н. p $^{20}$.

Стан справ 3 кількісним складом аспірантів та клінічних ординаторів стабілізується лише на 10 році діяльності ЧДМІ: у 1953-1954 н. р. проходило підготовку 16 клінічних ординаторів і 8 аспірантів ${ }^{21}$.

Одним із показників наукової діяльності ЧДМІ у перші роки своєї діяльності є кількість випускників вишу, які захистили дисертаційні роботи. Цей аспект результативності навчального закладу ніколи не залишався поза увагою педагогічного колективу інсти- 
Книжковий фонд наукової бібліотеки ЧДМІ (1944-1954 рр.)

\begin{tabular}{|c|c|c|c|}
\hline Роки & Книжковий фонд & Відвідувачі & Книговидача \\
\hline 1944 & 0 & 0 & 0 \\
\hline 1945 & 580 & 1263 & 3994 \\
\hline 1946 & 14000 & 17505 & 28890 \\
\hline 1947 & 19495 & 32073 & 46812 \\
\hline 1948 & 30170 & 35251 & 47297 \\
\hline 1949 & 36079 & 36045 & 54386 \\
\hline 1950 & 44598 & 54849 & 73921 \\
\hline 1951 & 52094 & 57616 & 83784 \\
\hline 1952 & 72732 & 63721 & 101265 \\
\hline 1953 & 82445 & 67581 & 125632 \\
\hline 1954 & 105173 & 69816 & 127760 \\
\hline
\end{tabular}

розробка питань, пов'язаних з фізіологією очей, винайдення низки приладів, на які отримано авторські свідоцтва, покращили офтальмологічну службу області.

3-поміж винахідників-науковців тих часів відзначимо також асист. Макоху, який отримав авторське свідоцтво на розроблену ним шину при лікуванні переломів бедра амортизаційно-екстензійним методом. Серед переваг шини Макохи перед іншими відомими на той час шинами були: рання ходьба, відсутність укорочения, відсутність гиксовання. У майстернях Центрального науково-дослідного інституту ортопедії виготовлено 5 шин, які направлено на випробовування у різні лікарні та інститути м. Москви ${ }^{31}$.

Учений Ф.А. Баштан започаткував дослідження чистоти та складу атмосферного повітря, питної води, грунтів. Свій винахід - прилад для визначення миш'яку (арсену) в об'єктах зовнішнього середовища - він впровадив у практику санітарної служби ${ }^{32}$.

Наукові дослідження співробітників ЧДМІ застосовувалися на практиці у виробничій сфері краю. Так, робота асистента Малиновського "Хімічна побудова сахаратів лужно-земельних металів" (1948р.) знайшла практичне застосування і була впроваджена у виробництво на місцевих цукрових заводах ${ }^{33}$; роботи проф. О.Ю. Мангейма, асист. Пеховича, доц. Аги, асист. Юнгельса "Травматизм на підприємствах трикотажної промисловості м. Чернівці" та проф. Л.Б. Теодора "Гінекологічна захворюваність працівників трикотажної промисловості" стосувалися вивчення виробничого травматизму в трикотажній і текстильній промисловості Чернівецької області ${ }^{34}$.

Висновки. Новий етап у становленні медичного інституту на Буковині проходив в умовах розладу мережі лікувальних закладів, відсутності приміщень і квартир для співробітників, засухи і голоду, вияву різних епідемій, нестачі медичних кадрів, відсутності електроенергії, водопостачання та опалення. Проте згодом, завдячуючи керівництву інституту, першим працівникам закладу (перші два роки роботи) вдалося відповідно обладнати навчальні корпуси, гуртожит- ки, квартири для викладачів. У цей період формується професорсько-викладацький склад, теоретичні та клінічні кафедри, налагоджується діяльність університетських клінік, відбувається координація співпраці 3 лікувальними закладами, заснована бібліотека. Фонд бібліотеки навчального закладу збільшується, покращується його якість порівняно 3 попереднім періодом. Наукова робота входить в організоване русло, поліпшилася матеріальна база наукових досліджень, хоча вчені вказували на недостатність реактивів, віваріїв, експериментальних виробничих майстерень. Видаються перші монографії, визначається тематика наукових робіт. За цей період працівниками навчального закладу було захищено понад 60 дисертаційних робіт, підготовлено й видано понад 500 наукових робіт. Інститут став лікувально-медичним центром області.

Завдяки роботі колективу зростає зацікавленість абітурієнтів. 3-поміж студентів збільшується кількість українців, однак кількість абітурієнтів з Чернівецької області ще залишається низькою. Наприкінці досліджуваного періоду відбулися вісім випусків ЧДМІ (1620 лікарів).

\section{Примітки:}

1. Перші проблемні комісії з наукової роботи були сформовані на засіданні вченої ради від 1 червня 1946 р.: організація охорони здоров'я (С.К. Лобинцев), зобна комісія (В.О. Ельберг), відновлювальна хірургія (О.Ю. Мангейм, Б.К. Осіпов) (див.: ДАЧО. - Ф. № Р-938. - Оп. 5. - Спр. № 14. Звіт ЧДМІ за 1946-1947 pp. - Арк. 9).

2. Тематичний план ЧДМІ у 1953 р. затверджено за 11-ма республіканськими проблемами: 1. "Зобна хвороба, іï лікування та профілактика" (в іiі підготовці взяло участь 10 кафедр). 2. Фізіологія та патологія вищої нервової діяльності (8). 3. Ліквідація туберкульозу (4). 4. Дизентерія і боротьба з нею (2). 5. Гіпогалактія і боротьба з нею (2). 6. Попередження та лікування нестачі кровообігу (6). 7. Профілактика i лікування отитів (1). 8. Профілактика і лікування гри- 
пу (1). 9. Профілактика і лікування скарлатини (1). 10. Профілактика і лікування раку (1). 11. Травматизм і боротьба з ним (1). Виконувались також позапроблемні теми (18), викладачі 18 кафедр працювали над дисертаційними роботами (див.: ДАЧО. - Ф. № Р -938. - Оп. 5. - Спр. № 202. Річний звіт про діяльність ЧДМІ за 1953-1954 н. р. - Арк. 84, 116).

3. У 1947 році захищена докторська дисертація завкафедри шкірно-венеричних хвороб М.Г. Безюка (у цьому ж році залишив роботу в ЧДМІ).

4. Аношкін Тимофій Антонович, народився у 1913 році в с. Щербенево Коливанського р-ну Новосибірської обл. в селянській родині, росіянин за національністю. Закінчив у 1937 p. Технікум сільського господарства у м. Бійську (спеціальність "зоотехнік"). У тому ж році вступив до Новосибірського медичного інституту, але у 1941 р. (5 курс) був мобілізований військовим лікарем, де служив до 1945 р. У лютому 1946 р. поновив навчання на 5 курсі ЧДМІ, закінчив ВНЗ і отримав кваліфікацію лікаря. Вступив до аспірантури при кафедрі нормальної анатомії ЧДМІ (див.: ДАЧО. - Ф. Р-398 - О. 1. - Спр. № 2. Архівні особові справи на співробітників, які покинули Інститут у 1944-1967 pp. - Арк. 145-165).

5. Касько Ювеналій Семенович на кафедрі дерматовенерології ЧДМІ пройшов шлях від клінічного ординатора й асистента (1950р.) до професора (з 1965 р.), попрацювавши 43 роки. 31956 до 1984 рр. завідувач цієї кафедри. Його ім'я внесено до галереї фундаторів наукових шкіл Буковинського державного медичного університету.

\section{Reference:}

\footnotetext{
${ }^{1}$ Boychuk T., Moysey A. Foundation of Chernovtsy State Medical Institute (1944-1946 gg.) / Boychuk T., Moysey A. // Bukovinian medical herald. - 2015. - № 4 (76). - Vol. 19. - P. 242-272; Bukovinian State Medical University: History and modern times (the 70th anniversary) [Boychuk T. M., Herush I.V., Bilookyj V. V. etc.]; Ed. T.M. Boychuk. - Chernivtsi: BSMU, 2014. - 272 p.: il, Boychuk T., Moysey A. Seventy years of Bukovinian State Medical University. History and Prospects of Development of Social Sciences and Ukrainian Studies Department // Current issues of social sciences and history of medicine. - 2014. - 1(1). - P. 7-18 p.

${ }^{2}$ State Archive in Chernivtsi Region (SACR). - F. R938. - O. 5. - File № 1282. - 1964. - Leaf. 2-3.

${ }^{3}$ SACR. - F. R-938. - O. 5. - File № 501. - Leaf. 73.

${ }^{4}$ SACR. - F. R-938. - O. 5. - File № 64. - T. 1. - Leaf. № 94, 99-101, 111 .

${ }^{5}$ SACR. - F. R-938. - O. 5. - File № 64. - T. 2. - Leaf. № 101 .

6 SACR. - F. R-938. - O. 5. - File № 64. . - Leaf. № 73 89.

${ }^{7}$ SACR. - F. R-938. - O. 1. - File № 39. - Leaf. № 1-2.

${ }^{8}$ Ibidem. - Leaf. № 14-15.

${ }^{9}$ Ibidem. - Leaf. № 17.

${ }^{10}$ Ibidem. - Leaf. № 2, 16.

${ }^{11}$ Ibidem. - Leaf. № 24.

${ }^{12}$ SACR. - F. R-938. - O. 5. - File № 14. - Leaf. № 46-
}

48

${ }^{13}$ SACR. - F. R-938. - O. 5. - File № 22. - Leaf. № 7172.

${ }^{14}$ SACR. - F. R-938. - O. 5. - File № 147.- Leaf. № 9293.

${ }^{15}$ SACR. - F. R-938. - O. 5. - File № 14. - Leaf. № 4648.

${ }^{16}$ Ibidem. - Leaf. № 3, 9, 50 .

${ }^{17}$ SACR. - F. R-938. - O. 5. - File № 147. - Leaf. № 185.

${ }^{18}$ SACR. - F. R-938. - O. 5. - File № 94. - Leaf. № 5253; SACR. - F. R-938. - O. 5. - File № 168.- Leaf. № $117,237$.

${ }^{19}$ SACR. - F. R-938. - O. 5. - File № 147. - Leaf. № 185.

${ }^{20}$ SACR. - F. R-938. - O. 5. - File № 15. - Leaf. № 122.

${ }^{21}$ SACR. - F. R-938. - O. 5. - File № 202. - Leaf. № 201.

${ }^{22}$ SACR. - F. R-938. - O. 5. - File № 289. - Leaf. № 32.

${ }^{23}$ SACR. - F. R-938. - O. 5. - File № 21. - Leaf. № 13.

${ }^{24}$ SACR. - F. R-938. - O. 1. - File № 7. - Leaf. № 1-4.

${ }^{25}$ SACR. - F. R-938. - O. 1. - File № 28. - Leaf. № 9798; SACR. - F. R-938. - O. 5. - File № 14. - Leaf. № 32

${ }^{26}$ SACR. - F. R-938. - O. 5. - File № 147. - Leaf. № 196-205.

${ }^{27}$ SACR. - F. R-938. - O. 5. - File № 14. - Leaf. № 41.

${ }^{28}$ Ibidem. - Leaf. № 13.

${ }^{29}$ SACR. - F. R-938. - O. 5. - File № 168. - Leaf. № 100-105.

${ }^{30}$ SACR. - F. R-938. - O. 5. - File № 202. - Leaf. № 114.

${ }^{31}$ SACR. - F. R-938. - O. 5. - File № 70. - Leaf. № 7-8.

32 SACR. - F. R-938. - O. 5. - File № 1281. - Leaf. № 120.

${ }^{33}$ SACR - F. R-938. - O. 5. - File № 186. - Leaf. № 37. ${ }^{34}$ SACR. - F. R-938. - O. 5. - File № 147. - Leaf. № 83 $-84$.

Boychuk T., Moysey A. Structure of Science research in Chernsvtsi State Medical Institute (1944-1954 years). Bukovina State Medical University has come a long and difficult way from the Institute and Academy of the University. This period was marked by significant achievements of its employees in different areas of medical science. One of the most valuable achievements of the university, is the the ground foundation of scientific schools, This researches began to take part in the Institute functioning through theese times. The most successfully functioning scientific schools was therapy, psychiatry, neurology, ophthalmology, histology, pathological anatomy, which was formed back in the $40-50$ 's XXth century. There was linked with such scholars as S.M. Savenko, V.A. Triggers, B.L. Radzikhovsky, N.M. Shinkerman, N.B. Shchupak, G.U. Malis, I.A. Shevchuk and others.

During this period was formed faculties, theoretical and clinical departments, university clinics. There was also cooperation with medical institutions coordinated, founded medical Library. The Library of the institution increased (from 508 books in 1945 to 105,173 books in 1954), its quality became better during this period. The number of visitors grows up from 1,263 to 69,816 , and books quantity changed from 3994 to 127 760 publish items. Research work was organized in all departaments, improved material base of research, but scientists have pointed to the lack of reagents, vivarium, experimental workshops. In that times was published the first monograph, defined 
subjects research.

During this period, the stuff of CSMU was finished more than 60 scientific theses, published over 500 scientific papers. During the first 10 years of CSMU organized and conducted over 20 scientific conferences, among which worth mentioning Conference variability of microbial dedicated endemic goiter, $\mathrm{X}$ Scientific conference CHDMI the results of research in 1948 on the issues of antibiotics, "Pawlowski reading " etc. An important achievement in scientific work CHDMI during marked period was founding of the Student scientific society in February 1945 . The institute became famous medical center in Bukovina region.

Thanks to the stuff of Institute, growing up interest of this medical esteblishment. The number of Ukrainian students became bigger, but the number of applicants from the Chernivtsi region remains low. At the end of the study period there have been eight issues CSMI consisting in 1620 young doctors.

Key words: Chernivtsy state medical institute, research work, scientific potential, the problem commission, professorteaching structure, postgraduate study, clinical internship, a student's scientific organization. 

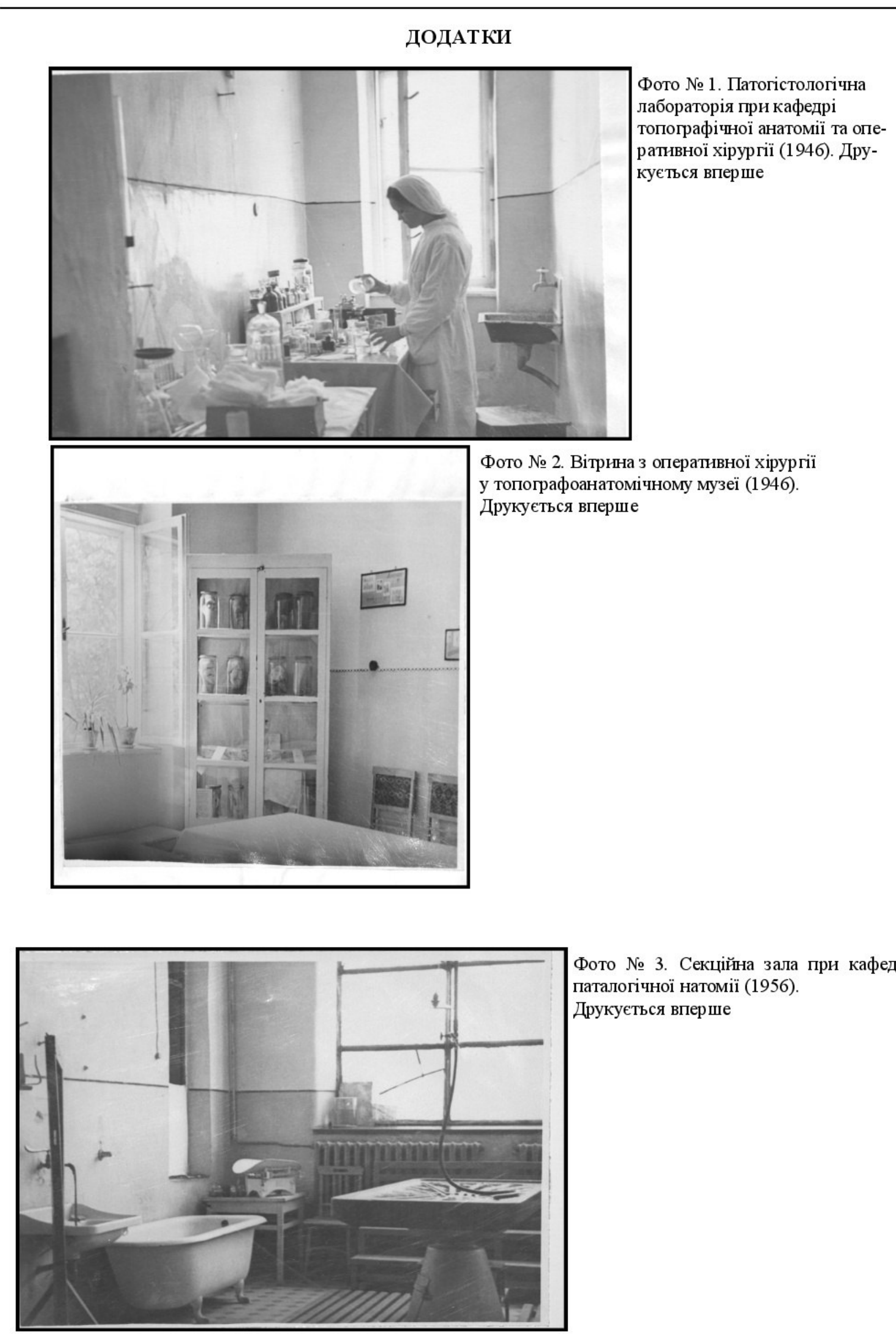

Фото № 3. Секційна зала при кафедрі паталогічної натомії (1956).

Друкується вперше 


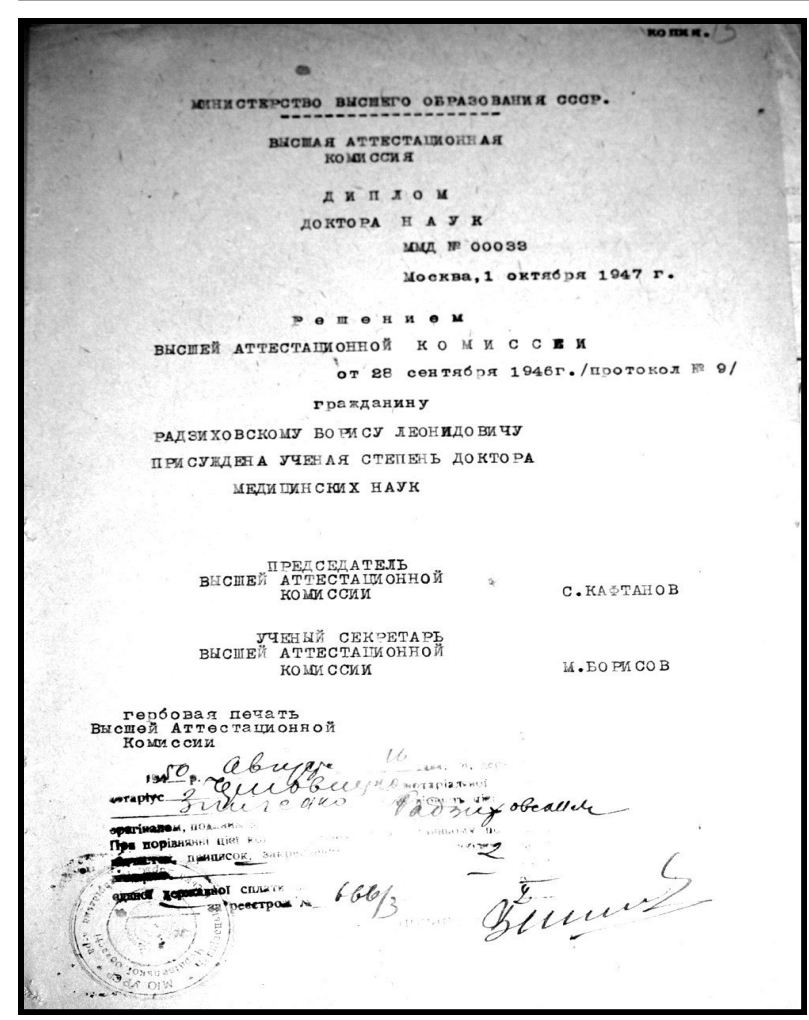

Фото № 4. Копія диплома доктора медичних наук Б.Л. Радзіховського (1947)

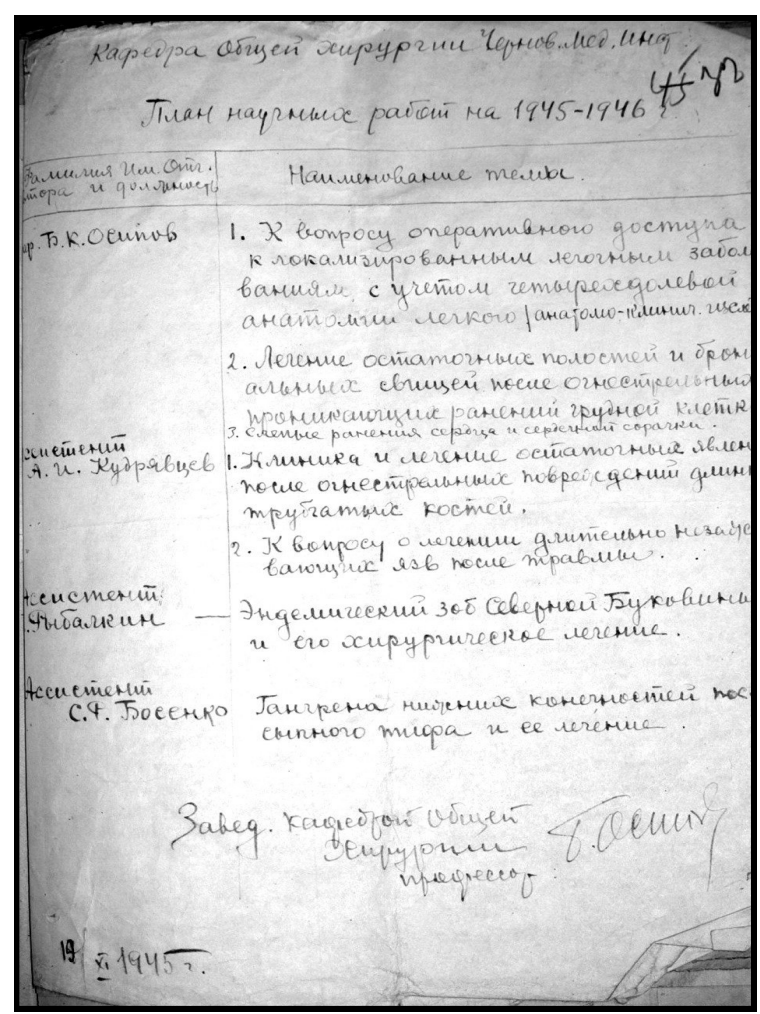

Фото № 5. Тематика наукових робіт кафедри загальної хірургії на 1945-1946 н. p.

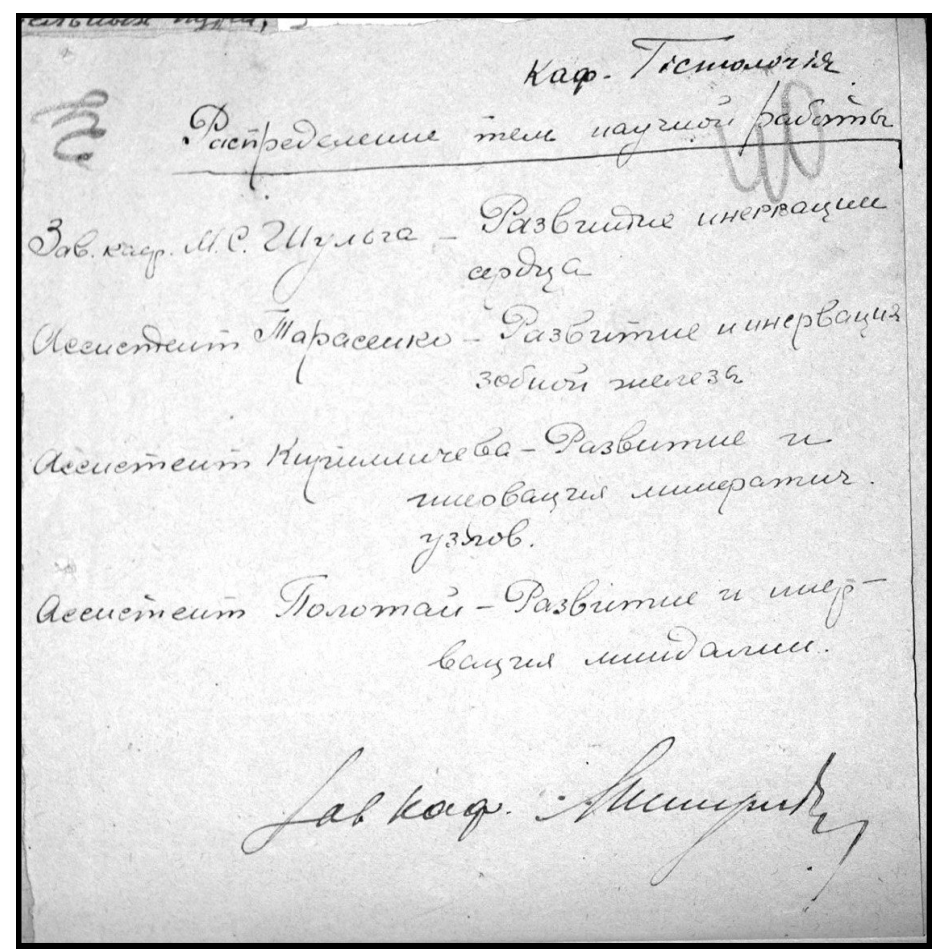

Фото № 6. Тематика наукових робіт кафедри гістології на 1944-1945 н. p. 


\section{ПРОГРАMA CECIY: \\ 9 грУАня 1945 р. О 11 гОА. Ранку}

1. Доң, К. Д. Філатова: „Макро-мікроскопія хрящевого остова бровхів" -20 х

2. Доц, Крични Д. І.: „Лікування тнойних пропесів гегенів" -20 хв.

Доктор медвчвих ваук проћ, Н. М. понесів легенів -20 хв.

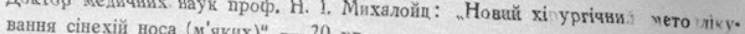

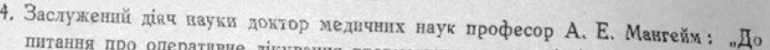

5. Доц. С. 1, Фланчик : Н лікувавия травматичвого остэоміэліта" -20 хв. дийних захворуваннях"

6. Дorgen

6. Доктор медичних наук проф. В. А. Эльберг: „Порушення обміну речовин хворих ревматизмом і шляхи його нормалізатіі" -20 хв

Доктор медичних наук проф. М. К. Венцківський : "До пютання про переважні шляхи розповсіодженвя раку штіик матки" (попередні повідомлеяня) - $10 \mathrm{x}$

8. Професор А. Н. Федорович: „Энтеровоковнй Коліг у дігей“ -20 хв. 9октор медичвнх наук проф. С. Н, Савевко: „Проблеми острого Энцефало міэліта та розсіянаого склероза 20 хв.

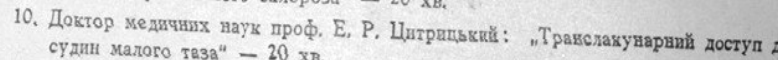

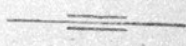

Фото № 7. Програма наукової конференції

Мойсей Антоній - доктор історичних наук, професор, завідувач кафедри суспільних наук та украӥнознавства ВДНЗ Украйни «Буковинський державний медичний університет». Коло наукових інтересів: історія украӥнської культури, історія Украӥни, традиційна культура населення Буковини, взаємовпливи в сфері традиційної культури українського та східнороманського населення Букови-ни, процеси етнокультурної ідентичності в прикордонних регіонах. Автор 175 наукових прачь, в тому числі 5-х монографій.

Moysey Antoniy - Doctor of Historical Sciences, Chief of the Social Sciences and Ukrainian Studies in Higher State Educational Establishment of Ukraine «Bukovinian State Medical University». Research inter-ests: history of Ukrainian culture, history of Ukraine, traditional culture of Ukrainian population, interplay in area of traditional culture of Ukrainian and eastromanian population of Bukovina, processes of ethnocultural identity in border regions. Author of 175 scientific publications including 5 monographs.
Бойчук Тарас - доктор медичних наук, професор, ректор Буковинського державного медичного університету, академік АН ВШ Украйни. Автор 262 наукових праиь, в тому числі 10 навчальних посібників та 8 монографій. Коло наукових інтересів: хронотоксикологія, лазерна поляриметрія біологічних об'єктів. Головний редактор наукових журналів „Буковинський медичний вісник”, „Клінічна та експериментальна патологія", „Неонатологія, хірургія та перинатальна медицина", „Актуальні питання суспільних наук та історії медииини”.

Boychuk Taras - Doctor of Medical Science, professor, rector of Bukovinian State Medical University, Academician of the Academy of Science of the Higher School of Ukraine. Author of 262 scientific publications including 10 textbooks and 8 monographs. Research interests of the author: chronotoxicology, laser polarimetry of biological objects. He is editor of scientific and practical journals „Bukovinian Medical Herald”, „Clinical and Experimental Pathology”, „Neonatology, Surgery and Perinatal Medicine”, „Current Issues of Social Sciences and History of Medicine".

Received 2.06.2016

Advance Acces Publischer: July, 2016

(C) T. Boychuk, A. Moysey, 2016 